PDFlib PLOP: PDF Linearization, Optimization, Protection

Page inserted by evaluation version www.pdflib.com - sales@pdflib.com 


\section{Is it Rational to Vote? \\ Five Types of Answer and a Suggestion}

Keith Dowding

\section{Introduction}

If rational choice theory is pathological (Green and Shapiro 1994), then nowhere has it displayed this trait more than in trying to explain why people vote. We know why people vote, or at least we know why people think they vote, because in surveys they have told us. The problem for rational choice theory is that the answer is boring, and it is not clear that it makes people instrumentally rational. People vote in order to express their preference for their preferred candidate, increase his or her chances of winning and because they feel they ought to. Not everyone gives all three reasons but all three reasons are present in any voting population. There might be other reasons too, but most can be reduced to one of these three. The problem for rational choice is whether people are rational when they vote for these reasons, and its attempt to show they are constitutes the pathology that Donald Green and Ian Shapiro identify. In this article I will examine the reasons rational choice writers have given for the rationality of voting. I suggest that they ignore the answers staring them in the face and need to switch the focus of their attention if they wish to provide deeper answers to the question than those given in survey responses. I will be suggesting, however, that despite its pathological quest for the holy grail of individually rational turnout, rational choice theory has turned up some interesting results.

\section{The Problem and Five Answers}

In decision-theoretic terms it is not rational to vote. A person will vote only if the rewards depending on their vote are greater than the costs of their voting: $p \mathbf{B}>\mathbf{C}$, where $p$ is the probability of someone's vote being decisive, $\mathbf{B}$ is the benefit gained through the voter's favoured party winning, and $\mathbf{C}$ the cost of voting. But $p$ is minuscule. Indeed, in large electorates the probability of being killed on the way to the polls may well be higher than the probability of being decisive (Goodin and Roberts 1975; Meehl 1977). This result is sometimes thought to be paradoxical, though as Carling $(1995,21)$ suggests,

in a novel unconventional sense, to mean a theoretical prediction, unsupported by the facts. Perhaps it is so called because if it sailed under its true colours as 'the false theory of voting', it would appear less well qualified to discharge its time-honoured function of bemusing generations of undergraduate students. 
Reactions to this problem from those sympathetic to rational choice theory have varied and can be placed into five general categories: ${ }^{1}$

1. To admit the problem, but dismiss it, and argue that whilst rational choice cannot explain why people get to the polls it can explain very well what they do when they get there. This is the marginalist solution.

2. Suggesting that the costs of voting are so small that people simply do not factor them into their decisions to vote. If we make $\mathbf{C}=0$ then $p \mathbf{B}>0$. This is the C-term solution.

3. By making the B term massive, by including global as well as self-interested utility in a voter's party differential. This is the $\boldsymbol{B}$-term solution.

4. By suggesting that people do not understand probabilities and so do not realise how unlikely it is that their vote will be decisive. Or by suggesting the $p$ term is defective and needs to be replaced by a calculation not involving decisiveness. These include replacing the maximisation of expected utility (EU) with a minimax regret criterion: the minimax-regret solution; using another framework to allow the value of $p$ to vary with strategic play by voters: gametheoretic solutions; or by replacing EU maximising with conditional expected utility maximising (CEU), the CEU solution. These are all $p$-term solutions.

5. To add a ' $\mathbf{D}$ ' term. By transforming the formula to $p \mathbf{B}+\mathbf{D}>\mathbf{C}$ one can explain why it is worthwhile for individuals to go to the polls. They still maximise their expected utility, but the work in utility terms is done by ' $\mathbf{D}$ '. These are $\boldsymbol{D}$-term solutions.

These potential answers to the problem are not necessarily rivals. The $p$-term and C-term solutions may have a lot of truth, but not be able to explain high levels of turnout on their own, but operate together with a D-term or a game-theoretic solution for example. We must also recall the famous Wuffeauldian credo of the reasonable choice modeller including 'Few people do things for only one reason' (Wuffle 1999, 203), to which we might add that different people often do the same things for different reasons. It is possible that some voters maximise expected utility, some use minimax-regret, some maximise conditional expected utility, some think game-theoretically, whilst others do not think at all. For some the costs may be low, for others high, for some ' $\mathbf{D}$ ' is important, though ' $\mathbf{D}$ ' may not mean the same thing to everyone. Some may only vote if they think they are going to be decisive whilst others simply want to contribute. In other words the reason why we get the turnout we do in any election can only be explained by an analysis of the reasons why each voter turned out. The causal explanation will be as messy as the world. However, the scientifically minded want deeper reasons that underlie and explain these responses; for classical rational choice that means making turnout individually rational, and individually rational in their own terms. In the final section I will suggest that people are individually rational, and perfectly so in terms of standard rational choice theory. But, the deeper explanation sought requires us to go beyond classical rational choice.

\section{The Marginalist Solution}

The marginalist solution is not offered as a 'solution' and rarely run on its own. Rather, it is a defence of the rational choice approach despite the problems inher- 
ent in the simple formula. Brian Barry $(1976,22)$ probably first used it as a defence of the 'economic approach to politics' in this context but Bernard Grofmann (1993, see also 1983 and 1996) has pressed the case most fully. He argues that we cannot expect rational choice theory to explain everything and its apparent failure to explain turnout is not really a problem. He supports the $\mathbf{D}$-term solution by suggesting that we may have a preference for voting, much as we have a preference for food (Grofmann 1993, 94) and suggests that there are many reasons for voting, some rational, some not, and so we cannot expect a model which explains absolute levels of turnout. ${ }^{2}$ Rather, rational choice is good at predicting at the margin. We should expect that when $p$ increases turnout goes up (that is, ceteris paribus, close elections should have higher turnouts), turnout should increase when $\mathbf{B}$ is larger (that is, ceteris paribus, when the parties are more extreme, or there is more at stake in the election), and turnout should go down as $\mathbf{C}$ goes up. These are testable hypotheses with some support. ${ }^{3}$

It seems on balance that voter turnout increases as elections get tighter. Andre Blais (2000, 58, Table 3.1$)$ reports 33 studies that examine closeness of which 28 suggest closeness increases turnout. These include four cross-national studies, of which two conclude that closeness does not affect turnout, 14 using cross-sectional US data that include the other three suggesting closeness is not effectual, 11 cross-sectional using data from countries other than the US, and four longitudinal studies. Other studies supporting closeness increasing turnout include Riker and Ordeshook $(1968,38)$ and Filer et al. (1993). However, closeness might be a proxy for mobilisation by parties and interest groups (Aldrich 1993, 1995 and 1997, 387-390; Matsusaka and Palda 1993; Shachar and Nalebuff 1999). Certainly parties and groups spend more in close elections (Cox and Munger 1989). Barry (1976, 17-18), recalculating Riker and Ordeshook's (1968) data, points out that closeness of election seems to have the greatest effect on those who do not feel such a strong moral obligation to vote. If closeness does independently affect turnout the effect is small.

Blais (2000) also discusses evidence that the size of the electorate affects turnout. The hypothesis is that in smaller electorates each person's vote counts for more, hence smaller electorates should have higher turnout. His Table 3.1 reports from 13 studies with seven suggesting the expected correlation exists and six not. There is no clear evidence that size affects turnout significantly.

Less evidence has been garnered with regard to the marginal considerations of the B term. Turnout is higher when the election is concerned with government's controlling higher levels of public expenditure which Josep Colomer (1991) interprets as meaning turnout increases the more important the election. Similarly turnout is higher in national than local elections (Blais 2000). Turnout is also higher in more proportional systems (Crewe 1981; Jackman 1987; Jackman and Miller 1995), implying voters are more likely to find amenable parties.

On the costs side the implications are clear. As voting costs increase turnout goes down. Compulsory voting increases turnout (Powell 1980 and 1982; Crewe 1981; Blais 2000; Colomer 1991, 35-36). Turnout is higher with automatic registration as opposed to registration by application (Powell 1980, 1982 and 1986; Crewe 1981; Jackman 1987; Jackman and Miller 1995; Colomer 1991). Turnout decreases with poll taxes and with literacy tests (Ashenfelster and Kelley 1975, 708; Filer 
et al. 1993), and where jury service is taken from voter registration lists, registration goes down (this has occurred increasingly in recent years with little correlation in the past suggesting that registration and willingness to serve on juries is related to decline in civic-minded behaviour) (Knack 1993). Distance and impedance matter too. Those further from polling stations or with tougher journeys are less likely to vote (Gimpel and Schuknecht 2003). Disabled people who are unemployed vote less than other unemployed (but disabled in employment vote as often as other employed people) (Schur 2000). Opportunity costs matter since weekend voting increases turnout (Mattila 2003). Anthony Downs (1957) points out these are not trivial matters. If real costs deter people from voting, those deterred will tend to come from the less educated, poorer social classes and those with disabilities. ${ }^{4}$ Indeed, evidence from a large number of democracies suggests that lower turnout is associated with less redistributive policies (Mueller and Stratmann 2003), whilst taxes and redistribution are higher in states with easier voter registration (Besley and Case 2003). It also demonstrates the importance of what might seem to be relatively trivial rules, such as the opening times of poll stations and the way voters (notably ethnic groups) are treated by those running the booths, and, to the extent that voting is habitual, especially how these factors affect firsttime voters. The marginal estimations illustrated by the simple decision-theoretic formula exhibit important ethical considerations.

Rain reduces turnout, but only amongst voters who show low civic duty (Knack 1994; Merrifield 1993). We may subtract from these costs the cost of not voting. This occurs when voters are pestered by canvassers asking them if they have voted yet. Whilst described by Iain McLean $(1987,47)$ as 'half-serious,' David Denver and others (2004 and citations therein; Niven 2004) have shown that local constituency campaigning has a significant effect on turnout. Strong party-group alliances are correlated with higher turnout (Powell 1980, 1982 and 1986), probably because of lower information costs and because groups encourage mobilisation (witness the role of churches in the 2004 US presidential election).

Group leaders may reduce costs and increase benefits. Carole Uhlaner (1989a, 1989b and 1993) and Rebecca Morton (1991) suggest that policy entrepreneurs may make a bargain with groups to provide specific policies whilst the group promises support. In these theories the role of groups is both to raise $\mathbf{B}$, by making people think the election is worth more to them, and increase the costs of not voting-a type of $\mathbf{C}$-term solution. However, these selective group benefits are still collective benefits for group members and so do not overcome the individual collective action problem (Green and Shapiro 1994, 52-53; Blais 2000, 7). Empirical evidence also offers little support (Green and Shapiro 1994, 53; Lapp 1999).

Overall the empirical evidence shows that the simple decision-theoretic formula does capture some of the considerations in the decision to vote. It has some explanatory force. Comparative analysis shows that costs and benefits, and closeness affect turnout. But, this does not show, of course, that people vote because $p \mathbf{B}-\mathbf{C}>0$, it only shows that $p, \mathbf{B}$ and $\mathbf{C}$ can independently affect their decision on whether or not to vote. Aggregate data tests cannot corroborate the formula; they can only demonstrate the marginal effects of each element of it. The only way of corroborating the formula is through stated preference evidence, checked against or used in tandem with revealed preference aggregate data. 
There is no doubt that the marginal defence of rational choice has some merit. The simple formula does point to influences on marginal changes in turnout. But, at the end of the day, it only shows that the variables in the simple formula matter, not that when people vote they do so rationally.

\section{The C-Term Solution}

Many writers have suggested that the costs of voting are negligible (Olson 1971, 164; Niemi 1976; Smith 1975; Aldrich 1993; Hinich 1981; Palfrey and Rosenthal 1985). Neglible costs here are those involved in going to the polls with McLean $(1987,46)$ even mentioning shoe leather. If the costs (and benefits) are indeed negligible, then as John Aldrich $(1993,261)$ suggests, rational people will not concern themselves with a cost-benefit calculation. We have seen however that when costs go up, turnout goes down. So, costs do matter, but the issue is whether or not for most people, most of the time, the costs of voting are so small they simply do not enter into a calculus of voting. The opportunity costs of going to the polls may be negligible. But, one must not forget the $p$ term. The probability of being killed on the way to the polls may not be much different from the probability of being decisive. It is relative costs that matter. Of course, the probability of being killed remains about the same whether you are going to the polls, the newsagents or to work, but in these latter activities one is more assured of getting what one actually went out for, but in voting $p$ is much smaller. However, only when the probability rises for specific reasons do people actually consider whether or not they are going to be killed when they leave the house and so it does not enter into their calculations. The problem for these $\mathbf{C}$-term solutions is that they miss the real costs.

Downs (1957) is usually credited with bringing the 'voting paradox' to our attention. However, the decision-theoretic form in which it is usually set out and discussed owes more to Riker and Ordeshook (1968) or Tullock (1967). Downs discusses the issue of course, and uses a version of the $\mathbf{D}$-term solution, but what motivates his discussion is whether voters should inform themselves about the issues. For Downs it is about the information costs, not the opportunity costs of the act of voting itself. The problem for the rational voter is that:

the party which eventually wins will probably be elected no matter how he casts his ballot, as long as the other citizens vote independently of him. Thus the cost of his making a mistake cannot be measured by his party differential, since this mistake may not alter the outcome.

Instead he must discount his party differential greatly before arriving at the value of voting correctly. This vote value is compounded from his estimates of his party differential and of the probability that his vote will be decisive. Since the vote value measures the possible cost to him of being inadequately informed, it is from the vote value, not the party differential, that information relevant to voting derives its worth. We must therefore substitute the vote value, which is nearly infinitesimal under most 
circumstances, for the estimated party differential in all the calculations outlined above. The result is enormously diminished incentive for voters to acquire political information before voting (Downs 1957, 244-245).

The problem for Downs is that the benefits from efficient social organisation are indivisible, so it is rational to free-ride. Downs assumes efficient government will occur when every voter expresses the views they would have if they were the decisive voter:

But in fact his vote is not decisive: it is lost in a sea of other votes. Hence whether he himself is well-informed has no perceptible impact on the benefits he gets. If all others express their true views, he gets the benefits of a well-informed electorate no matter how ill-informed he is: if they are badly informed, he cannot produce these benefits himself. Therefore, as in all cases of indivisible benefits, the individual is motivated to shirk his share of the costs: he refuses to get enough information to discover his true views. Since all men do this, the election does not reflect the true consent of the governed (Downs 1957, 246).

Information costs are the real problem and the genuine predicament for Downs is ignorant voting, not non-voting. Recent game-theoretic work has shown that the better informed should be more likely to vote, with the less informed delegating to those with better information (Fedderson and Pesendorfer 1997), though these effects reduce with heterogeneous populations (Caillaud and Tirole 1998). Decision-theoretic models yield similar results (Matsusaka 1995) where confidence in one's views drives utility levels from the act of choice. One of Downs' solutions to the information problem is ideology (see Hinich and Munger 1994) and using British Election Study data Valentino Larcinese (2000) has demonstrated that ideological motivations affect information acquisition and both influence turnout (see also Lassen 2005). But, again these results show that costs have marginal effects (the less ideologically motivated the higher the costs of information acquisition) rather than show it is rational to vote. One answer might be Aristotelian, that is 'man is a political animal' and the information costs are not costs but benefits. We enjoy collecting political information, not simply because it is fun, but because it is useful to us. Benz and Stutzer (2004), using data from Switzerland and the EU, show that people become better informed when they have more extended participation rights. However, assuming or demonstrating that we enjoy collecting political information does not show that it is rational to vote, even if those who have more information, rationally, are more likely to vote. I will return to the Aristotelian dictum at the end.

\section{The B-Term Solution}

The low probability of being decisive might not matter if the benefits are really high. Howard Margolis (1982, ch. 7) suggests that altruism might allow this. He argues that goods-altruism-where one's utility from a good is composed of the material interest of oneself and others might make B high enough. Whether we 
can get goods-altruism to make $\mathbf{B}$ high enough to be higher than even low costs of voting given ' $p$ ' in part depends upon the value of ' $p$ '. McLean $(1987,46)$ makes $p=0.00000006$ for British general elections and Mueller (1989) makes 0.00006 for a US presidential one. ${ }^{5}$ Both recognise these are generous. The latter figure is derived by assuming the expected probability of everyone voting for one or other candidate to be exactly 0.5 (a coin toss) and then computing $p$ from the exponential approximation to the binomial formula. However, this low figure is based upon the extreme assumption of exact equiprobability of voting for each candidate. The gradient of the function is extremely steep and Brennan and Lomasky (1993, ch. 4) show that marginal deviations from equiprobability dramatically alter the calculation. Carling (1995) estimates that if you assume the probability is 0.499 , the probability of casting a decisive vote in US presidential elections becomes $10^{-90} .^{6}$ Do winners make so much difference even globally given very low costs of voting? No matter how you consider the matter, the reason for voting, based on the benefits directly consequent upon the act, get destroyed by the resonation of $p$ the probability of being decisive. The $p$-term continually mucks up rational voting.

\section{$p$-term Solutions}

One obvious solution is to change the nature of the calculation by changing the nature of the $p$-term or getting rid of it altogether. There are at least six general approaches to this:

(1) by suggesting that people do not understand the true $p$ figure and so overestimate their decisiveness;

(2) by using a minimax-regret criterion rather than expected utility calculation;

(3) by using game theory to change the calculation of $p$;

(4) by replacing expected utility theory with evidential or conditional expected utility calculations;

(5) by using adaptive behaviour models;

(6) by claiming no one cares if they are decisive.

\section{(1) p-overestimation}

It is well known that people have a poor understanding of probabilities (Kahneman et al. 1974). Some writers suggest that voters may simply misunderstand the probability that their vote is decisive (Riker and Ordeshook 1968; Barzel and Silberberg 1973, 53), partly subject to propaganda put out by parties and the state (Brunk 1980). Blais (2000) provides stated preference evidence that individuals massively overestimate the probability of their decisiveness. ${ }^{7}$ But, even on these estimates the probability of being decisive is small and, whilst it may provide the basis for a Margolis B-term solution, other stated preference evidence suggests otherwise. When asked why they vote few people cite the probability that their vote will be decisive. Indeed, they are rarely questioned in this manner but rather asked if they are more likely to vote when the election is close (Dennis 1991) and I suspect would query the sanity of the interviewer if they were directly asked the question. Decisiveness does not enter into individuals' decision framework when deciding to vote. 


\section{(2) Minimax Regret}

John Ferejohn and Morris Fiorina (1974 and 1975) suggest that elections are not occasions when probabilities of victory can be calculated. Rather, they involve decision-making under uncertainty. They use a once-popular decision-theoretic device when faced with uncertainty-minimising one's maximum regret—-to explain why people vote. If the result in one's constituency was tied, or lost by one's side by one vote, then one would really regret not having voted. Given the low costs of voting, one votes. In other words, since $p$ is unknown, it drops out of the calculation. The most obvious objection is that elections are not that uncertain (Aldrich 1993; Beck 1975, 259). It cannot explain higher turnout in close elections (Palfrey and Rosenthal 1985), and cannot explain turnout in safe seats or when the result is a foregone conclusion. It has the implication that turnout should increase when more extreme candidates stand even when they have low support (Mueller 2003, 308).

\section{(3) Game-Theoretic Explanations}

Another way of transforming $p$ is to recognise that it is not a fixed probability. After all, if $p$ is very small then no one will vote. But, if no one votes, $p$ will not be very small so it may be rational to vote. But, if everyone works out that they should vote then $p$ will be very small (first noted by Downs 1957, 267). Models in which $p$ is endogenously determined by the interaction of strategically minded voters can generate equilibria with high turnout rates (Palfrey and Rosenthal 1983), but once the assumptions of complete information about the preferences and voting costs of others are relaxed the high turnout falls (Palfrey and Rosenthal 1985). The game-theoretic models tend to predict much lower turnout rates than seen in the world (Ledyard 1981 and 1984), and turnout drops to zero as parties converge on the median voter (Morton 1991). Game theory does not in fact add much to the decision-theoretic formulation, largely, I suspect, because the strategic considerations are negligible since there are so many other players; it is as though each voter is playing against nature and the strategic considerations are wrapped up within the ' $p$ ' term. However, game theory has suggested two approaches that allow a form of strategic behaviour to re-enter, as the ' $p$ ' term is made irrelevant, to generate high turnout. These are the conditional expected utilty models, and models of adaptive behaviour.

\section{(4) Conditional Expected Utility (CEU)}

The problem for rational turnout is that one's vote is causally not going to make much difference to the outcome. Thus, if we are going to try to give an account of the rationality of voting we have to break the link between voting-rationality and the material benefits consequent upon my vote. Are actions, for instrumentally rational actors, only justified by what they cause? Robert Grafstein (1991 and 1992, ch. 6) argues that the game-theoretic version of rational turnout can be saved by replacing the causal decision theory component by Richard Jeffrey's (1983) evidential decision theory (CEU). According to Jeffrey it is rational to act in any way 
that provides higher expected utility. If a given action causes our preferred outcome then obviously it is rational for us to act thus. Most of the time therefore, evidential decision theory and causal decision theory recommend the same actions. But, our actions directly causing something is not actually contained in Jeffrey's logic of decision. For Jeffrey any evidential link between an action of type $x$ and an outcome of type $y$ justifies my doing $x$ even if it is not going to cause the outcome $y$ I desire. It would be justified for me to give up smoking if smoking and cancer are strongly correlated, even if it is demonstrated that smoking cannot cause cancer. Grafstein (1999) has an extended defence of CEU against claims that no matter how predictively accurate it may be, it represents irrational behaviour.

Under evidential decision theory it is rational for me to vote for my favourite candidate if there is a statistical relationship between people like me voting for that candidate, and the number of votes they receive. Now, whilst it is undoubtedly true that there is a strong statistical relationship between people voting for individuals and their probability of winning, why should this make a difference to whether I should vote, even if the voters for my favourite candidate are like me? My vote will not cause people like me to vote, nor will my voting because I think people like me will vote cause people like me to vote. Indeed, such thinking is used by causal decision theorists to suggest the irrationality of non-causal evidential decision theory.

Grafstein uses an analogy to support his idea. I wish to meet a colleague before he reaches work and know that he has only two possible routes by which he may walk. I know that my colleague has very similar tastes to myself, and therefore it seems sensible to wait on the route that I would walk myself if I were faced with the same journey. True. But, the analogy fails. If my colleague is going to walk one of two routes, I can use evidence about him to guess which route he might walk (and I can do this if he is like me or not). What I cannot do is to induce someone to go for a walk along a route one day by going for that walk myself, no matter how alike we are. Nor can I increase the probability of you going for a walk by going for one myself, or inducing more walking behaviour in you by walking more myself. That is the correct analogy with voting. ${ }^{8}$

\section{(5) Adapative Behaviour}

Bendor et al. (2003) have recently produced an adaptive behaviour model of turnout and run a number of simulations to produce high levels of turnout (50 per cent), even with large electorates. The adaptation that people learn is to vote or not to vote depending on trial-and-error behaviour with reinforcement based upon the results of the election when they vote or do not vote. The model relies upon an aspiration level which is a threshold that partitions all pay-offs into successful or unsuccessful ones. Each player has two choices, to vote or not vote. The model assumes there are two factions, say Democrat and Republican, and the winning faction gains a pay-off $(\mathbf{B})$ and losers get nothing. There is a cost to voting $(\mathbf{C})$, and winning voters get $\mathbf{B}-\mathbf{C}$, winning non-voters get $\mathbf{B}$, losing voters get -C and losing non-voters get 0 . An action deemed 'successful' is reinforced, such that the person does the same action next time with some probability below unity (that is, there is a 'tremble'). So, if someone votes and the pay-off is greater than 
their aspiration level their propensity to vote next time increases; if it is less it decreases. Aspirations also adjust probabilistically in the model, with the next round's aspirations a weighted average of the previous round's aspiration level and pay-off.

How does the relatively high turnout come about? If no one votes and aspiration levels are $\mathbf{B} / 2$ then, in a world without trembles, non-voting would be a stable equilibrium. But, with a tremble one person will vote, be decisive in the election, and the action will be successful. The non-voting winners' behaviour will also be reinforced. However, the non-voting losers have just had negative reinforcement since their side lost. They now have a pay-off of 0 with aspiration levels of $\mathbf{B} / 2$. Hence at the next election all the losers will vote with some probability. The losers last time will win this time, and this round's winners' propensity to vote will be reinforced, the non-voting winners' behaviour will be reinforced, the losing nonvoters and the voting-non-winning losers have their behaviour negatively reinforced, and so on. Making aspiration levels always higher than 0, and lower than B - C ensures this result.

Bendor et al. (2003) produce an Aspiration-Based Adaptive Rule (ABAR) which essentially is any 'learning' mechanism in which 'successful' actions are reinforced and 'unsuccessful' ones are inhibited. It entails that winning voters and losing nonvoters increase their propensity to vote next time since their behaviours correlated respectively with winning and losing; whilst winning non-voters and losing voters decrease their propensity to vote next time, again because their behaviours correlated respectively with winning and losing. The organisms in this model simply continue the activities that correlate with success.

This model successfully maintains turnout of 50 per cent no matter how large the electorate. However, it is not clear what this has to do with voting in the real world; specifically what it has to do with rational voting. I vote (do not vote) next time if voting correlated with my side winning, and vote (do not vote) if not voting correlated with my side losing. This predicts that non-voting losers will (almost) always vote at the next election and voting losers will (virtually) never vote at the next election, something which is clearly not sustained by empirical evidence.

Actions that correlated with 'success' last time are reinforced, but success is just happenstance and is not caused by most actions. What seems to be learned in this stochastic learning model is diagnostic behaviour. Now, this may be a good model to explain behaviour of non-reasoning creatures, but it seems to be no more a rational account of voting than Grafstein's. What both may contain however are the seeds by which to grow an account that is consistent with (stated preference) empirical evidence. We may see conditional expected utility models, or adaptive behaviour models, not as rational explanations of human behaviour, but rather as unthinking rules that organisms use because they are successful strategies for their genes. I consider this in the final section.

\section{(6) Who Cares if They are Decisive?}

The decisive voter is the one whose vote ensures their side wins. It breaks the tie. Who wants that? Nobody who knows anything about politics. Politicians do not 
want to win by one vote. It is very difficult to rule in the UK without a secure majority in the House of Commons of at least 20 seats and prime ministers are far more powerful the larger the majority. Similarly, MPs do not want to win seats by one vote. They want large majorities, and 'safe' seats, that is seats that will not be targeted by opposing parties, putting in a lot of resources at the subsequent election. Thus, parties work hard not simply to secure victory, but victories by large margins (Stigler 1972). ${ }^{9}$ Only perhaps a president is happy with a one-vote victory-but as the events in the USA in 2000 demonstrated that is rather too close. ${ }^{10}$ Furthermore, at more elections people vote at various levels (Schwartz 1987; Dunleavy and Margetts 1995) and evidence shows this increases turnout (Mattila 2003). Even so this does not straightforwardly overcome the $p$-problem. I may want my one vote to help my side to a larger majority. As Patrick Dunleavy has suggested in various unpublished writings, people want to 'have a useful effect'. The problem for this answer is that the useful effect is one vote, and one vote does not a safe seat make. Wheresoever one puts the margin of victory, at one vote, or a large majority, the one vote that each voter makes is only one. If it turns a loss into a tie (and in Britain a tossed coin), or a tie into a win then a voter may feel decisive. ${ }^{11}$ What did the Labour voters of Easington feel when they secured the margin of victory of 30,012 at the 1997 British general election. Did each revel in the fact that they could see what 'useful effect' their vote had made? Were they proud that they had secured the largest Labour majority in the country? At what point would voters decide there was no more useful effect for them to have? Can we develop any empirically testable hypotheses about such voting? The problem for the criterion of 'having a useful effect' is that it appears to be an expressive value masquerading as an instrumental one. ${ }^{12}$ Knowing that one had helped to secure one or more victories (or helped stop such a bad loss) is simply to claim that one gains utility from contributing to a collective effort (Hinich 1981). That is okay as an empirical claim, but not as a defence of the rational choice approach. ${ }^{13}$ So, let us leave decisiveness. It has always been a red herring.

\section{D-term Solutions}

Riker and Ordeshook (1968) introduce the D term, allowing the benefits of voting to outweigh the costs because people gain satisfaction through voting through 'compliance with the ethic of voting', 'affirming allegiance to the political system', 'affirming a partisan preference' and 'affirming one's efficacy in the political system'. Essentially the D term, which can cover all sorts of private motivations, is an 'expressive benefit'. ${ }^{14}$ In terms of the empirical stated preference evidence, the $\mathbf{D}$ term is the most efficacious in getting people to the polls (Riker and Ordeshook 1968; Ashenfelster and Kelley 1975; Knack 1992; Blais 2000; Mueller 2003).

We may recall Barry's (1976, 17-18) calculation that closeness of election has the greatest effect on those who do not feel such a strong moral obligation to vote and Knack's (1994) finding that rain does likewise. In other words, duty gets people to the polls and the costs and benefits bite most on those with low civic duty.

Yet, the D-term solution is the one that critics have poured most scorn upon. It might seem strange that critics, such as Green and Shapiro (1994) who criticise 
rational choice for producing so few empirical successes, should seem so critical of the D-term solution when it seems empirically to have so much going for it. The answer is that as an expressive benefit people believe it goes outside the instrumental rationality from which rational choice models derive their power. Many have quoted Brian Barry $(1976,16)$ :

Riker says that people vote because they derive satisfaction from voting for reasons entirely divorced from the hope that it will bring about desired results. This may well be true but it does not leave any scope for an economic model to come between the premises and the phenomenon to be explained.

Similarly Mueller $(2003,306)$ :

Without a theory explaining the origin, strength, and extent of an individual's sense of civic duty, merely postulating a sense of civic duty 'saves' rational egoism by destroying its predictive content.

In fact, models of expressive voting (Brennan and Lomasky 1993; Schuessler 2000 and 2001) do produce predictions that are consistent with empirical evidence. The marginal considerations we saw above still operate with an expressive component. ${ }^{15}$ The expressive component could not be the whole story or voters should not be too upset if it turns out the ballot box where they cast their vote was compromised so their vote was not counted. But voters do get upset, which suggests expressing yourself is not the only factor, especially since many people want to keep their actual vote secret. Furthermore, if all one wanted was to express a preference then there would be no room for tactical voting and there is evidence that some vote strategically (Cox 1997; Franklin, Niemi and Whitten 1994).

Nevertheless the ' $\mathbf{D}$ ' answer, despite being simple, despite being empirically verified by stated preference evidence, consistent with aggregate data evidence, and, if not properly tested, corroborated by Barry's and Knack's evidence, does not find much favour amongst political scientists whether rational choice advocates or critics. ${ }^{16}$ Why? Because they want deeper reasons.

\section{The Desire for Deeper Reasons}

That people vote for a variety of ' $\mathbf{D}$ ' reasons is certainly true. People do feel an obligation to vote. They enjoy expressing their preferences, especially when ideologically committed. They are aware that their vote is not likely to be decisive, but do want to try to help their side, especially when they think the election is important. They turn out more when elections are close because they want to influence the result, and less when the costs increase. The costs are low for most people most of the time, but when costs increase turnout goes down. There are real costs of not voting and when these are made higher by the tactics of canvassers, voting goes up. The less informed are less likely to vote than the more informed, which is perfectly rational, and those who are informed almost certainly do not consider informing themselves a cost. They enjoy politics, or at least it matters to them even if they engage out of anger and frustration. Humans are political animals and maybe we vote in order to justify our interest in politics. ${ }^{17}$ We are not merely spec- 
tators but combatants too. All of this is consistent with the rational choice approach to the study of politics. Classical rational choice may not explain in a deep and interesting manner why people vote ('it's the "D-term"') but adding it to the simple formula does not destroy predictability even if adding the D-term does not help us produce point predictions of turnout in any election. We still produce predictions at the margin which is all economics and political science have ever done. If feelings of obligation go down in a society then political participation should go down. This, of course, is the social capital argument of Robert Putnam (2000) and others (see Milner 2001). It is simply false that we get no predictions.

These facts will not stop the desire for deeper reasons, however. And nor should they. But, if we want to explain why people feel a duty to vote, and why they have an interest in engaging in politics even though many of their efforts are futile, we need to take a serious look at human psychology (Mueller 2003, 329-332). There is still a problem amongst rational choice writers (and their critics) in confusing utility maximisation (an analytic claim) and self-interested utility maximisation. The above quote from Mueller (2003)—the best extant textbook on rational choice-is illustrative. Individuals maximise their utility by definition. We assume this in order to allow us to interpret what people are doing and do so formally in order to mathematically manipulate to produce testable predictions. If one does one's duty, then doing one's duty is part of one's utility function. The deeper question is why is duty- to a lesser or greater extent-part of people's utility function? And, another branch of rational choice theory can help answer that question where classical rational choice provokes only the need for the question.

Humans feel obligations because it has been to their evolutionary advantage (Dowding 2001). We are poor at calculating the probability of our decisiveness (but good at working out differences between high probability events) because being poor at such calculations has no effect on our propensity to survive. People may well act diagnostically (as Grafstein maintains) because it gives competitive advantage to such populations. That does not make it classically rational. People may well use decision heuristics (Cosmides and Tooby 1992) along the lines of Bendor et al.'s adaptive behaviour model because it works, but neither does that make it classically rational. ${ }^{18}$ Such behaviour can be explained through evolutionary game theory (Gintis 2000), where the players are genes and the outcomes are phenotypes, and we are the carriers of phenotypes. That is, our behaviour is the equilibrium of these games much as in classical game theory, but we are a collection of equilibria rather than the players. Humans, because we explain our actions intentionally, are more likely to come up with classically rational explanations for our behaviour and, when we spot we that do not behave in accordance with classical rationality we may well see personal advantages in doing so, even if, in the long run, doing so is bad news for our genes. One can learn to defect in collective action games (Marwell and Ames 1981; Blais and Young 1999).

The lesson to be learned is that when examining human motivation-which is what the 'why vote?' question is about-we need to delve properly into human psychology and not simply try to make it fit with some predetermined modelling techniques, no matter how useful those techniques are at answering other questions. For that reason, the 'why vote' question may not be properly a part of 
political science-unless it is a branch of political psychology. Political scientists need only consider the marginal structural considerations affecting differential turnout levels as examined, for example, in Franklin (2004).

\section{About the Author}

Professor Keith Dowding, Government Department, London School of Economics \& Political Science, Houghton Street, London WC2A 2AE, email: k.m.dowding@lse.ac.uk

\section{Notes}

1. Another answer is that people vote because it is habitual. Strong evidence shows that voting and non-voting are habitual, but being a habit does not show why one votes or does not vote initially (Plutzer 2002; Franklin 2004), nor whether the habit is rational. I say something about this aspect below.

2. Grofman's views echo Wuffle's here, and both claim to be 'reasonable choice modellers'. It is not always clear who should be given credit for their coincident views.

3. It is not my intention to review the evidence here, considering the techniques used and how robust the conclusions, merely to report the findings. Critical reviews of the empirical evidence can be found in Aldrich 1993; Green and Shapiro 1994, ch. 4; Mueller 2003, ch. 14; Franklin 2004; and, most comprehensively, in Blais 2000.

4. Some people have claimed that richer people will vote less since the opportunity costs of voting are lower. But, this assumes that richer people are less likely to take leisure time since they can earn more in their leisure hours than poorer people. This is simply false. Often wage-earners can earn overtime whereas the salaried do not receive more money for putting in longer hours, especially later in their careers (earlier it may lead to promotion). Furthermore, as Downs points out, if time must be taken off work to vote, wage-earners may lose money, but the salaried not.

5. The new edition Mueller $(2003,304-305)$ does not now give this estimate but gives a nice short discussion of how to calculate the odds. I cite the earlier calculation simply because it was widely cited.

6. The originators of the problem made it $10^{-8}$ (Riker and Ordeshook 1968, 25). Others who give formulae for the calculation include Owen and Grofman (1984); Beck (1975); Mayer and Good (1975); Margolis (1977); Peters (1998); Shachar and Nalebuff (1999); and Fischer (1999). Statistical forecasting models using empirical data to estimate rare events give higher estimates of $p$ though still around 1 in 10 million for US presidential elections (lower in some states than others; as low as 1 in 1.5 million in some swing states in close elections) (Gellman et al. 1998). In other words the calculation in not trivial and subject to dispute.

7. That is according to the probabilities of $p$ I am assuming, Blais, using probability calculations aligned with Mueller (1989), suggests people have a better idea of the probabilities than many assume. In other words, he, like his subjects, massively overestimates the probability of each voter being decisive.

8. Indeed, we might note that my attempt so to do will increase the distance between how alike we are, unless of course you reason in the same strange manner. Why should Grafstein want to defend CEU as 'rational'? More generally, why should we want to try and defend the voting act as a rational one? And, it is not just rational choice writers who wish to do that. Even their most trenchant critics such as Green and Shapiro (1994) and Udehn (1996) do not want to claim voting is irrational, they just want to claim that rational choice does not have a unique claim on rationality. Only psychologists seem prepared to point to human irrationality, indeed revel in it, and even then many do not want to suggest that voting is irrational in the sense of the money pump. The reason perhaps is clear. Most of us vote, and those of us who are political scientists may have a special interest in this not being irrational.

9. This may be illustrated by the attitude of the blue rinse Margot in the 1970s comedy The Good Life, who rallied Conservative supporters after the great shock of Labour not losing their deposit in Surbiton. When I was election organiser for Andrew Smith, MP in Oxford East over a series of elections, our first aim was to win the seat from the Conservatives, then to secure a safe majority, and then to win over 50 per cent of the votes. The long-term aim was to stop the seat from being a Conservative target to make our job easier in the future. By the 1997 election we were sending workers to neighbouring constituencies. 
10. Of course the one vote is for majority in the electoral college, not the popular vote. The 2000 US election shows one can win even without the decisive vote (Mebane 2004; Imai and King 2004). In fact US presidents want large majorities too, both for legitimacy and for the coat-tails effect on Congressional elections.

11. The actual rule is that the Returning Officer 'draws lots' which in practice (at least at the local level) has meant tossing a coin between the two tied candidates. Prior to 1984, the Returning Officer had a casting vote which was last used in Ashton-under-Lyne in 1886. There have been no one-vote majorities in parliamentary elections in the UK. Winchester in 1997 was won with a two-vote majority as was Ilkeston in 1931.

12. This type of collective action problem resembles a Sorites paradox. When does a pile of stones cease to be a pile of stones if you take away one stone at a time? Or, conversely, when does it become a pile of stones if you add one at a time. Perhaps, if the costs are very low, people are happy to add one stone, or one vote to the tally, but do they do this for instrumental or expressive reasons?

13. Dunleavy's account is more obviously expressive when he says that people want to 'own' results (Dunleavy and Margetts 1995). He may also have a more radical critique of subjective expected utility theory lurking somewhere in his writings (Dunleavy 1997), but if so it will probably turn out to be Grafstein's.

14. The most comprehensive account of expressive voting is Brennan and Lomasky (1993), also Schuessler (2000 and 2001). I will not say much about these subtle and interesting accounts here. Essentially they suggest that people vote in order to cheer their side on.

15. In fact Mueller $(2003,322-326)$ does discuss how much of a voter's utility function might be 'altruistic' and shows how predictions might be generated.

16. The causal story may run in the other direction. Habitual voters justify their voting in terms of civic duty since they cannot rationalise it any other way. Nevertheless, those who claim duty do seem less inclined to turn out when costs go up marginally.

17. We might try to strengthen this argument, and say that the fact we are political and want to engage in politics legitimises our participation in democracy. In other words, we vote in order to rationalise our bothering to collect political information in the first place.

18. Though such models need to be applied less clumsily to voting behaviour.

\section{Bibliography}

Aldrich, J. H. (1993) 'Rational choice and turnout', American Journal of Political Science, 37, 246-278.

Aldrich, J. H. (1995) Why Parties? The Origin and Transformation of Party Politics in America (Chicago: University of Chicago Press).

Aldrich, J. H. (1997) 'When is it rational to vote?', in D. C. Mueller (ed), Perspectives on Public Choice (Cambridge: Cambridge University Press), 373-390.

Ashenfelster, O. and Kelley, Jr., S. (1975) 'Determinants of participation in American elections', Journal of Law and Economics, 18, 695-733.

Barry, B (1976) Sociologists, Economists and Democracy (2nd edn) (Chicago: Chicago University Press).

Barzel, Y. and Silberberg, E. (1973) 'Is the act of voting rational?', Public Choice, 16, 51-58.

Beck, N. (1975) 'The paradox of minimax regret', American Political Science Review, 69, 918.

Bendor, J., Diermeier, D. and Ting, M. M. (2003) 'A behavioral model of turnout', American Political Science Review, 97:2, 261-280.

Benz, M. and Stutzer, A. (2004) 'Are voters better informed when they have a larger say in politics?', Public Choice, 119, 31-59.

Besley, T. and Case, A. (2003) 'Political institutions and policy choices: evidence from the United States', Journal of Economic Literature, 41, 7-73.

Blais, A. (2000) To Vote or Not to Vote: The Merits and Limits of Rational Choice Theory (Pittsburgh, PA: University of Pittsburgh Press).

Blais, A. and Young, R. (1999) 'Why do people vote? An experiment in rationality', Public Choice, 99, 389-403.

Brennan, G. and Lomasky, L. (1993) Democracy and Decision (Cambridge: Cambridge University Press).

Brunk, G. G. (1980) 'The impact of rational participation models on voting attitudes', Public Choice, 35, 549-564. 
Caillaud, G. and Tirole, J. (1998) 'Voters homogeneity and aggregation of information', unpublished.

Carling, A. (1995) 'The paradox of voting and the theory of social evolution', in K. Dowding and D. King (eds), Preferences, Institutions and Rational Choice (Oxford: Clarendon Press).

Colomer, J. M. (1991) 'Benefits and costs of voting', Electoral Studies, 10:4, 313-325.

Cosmides, L. and Tooby, J. (1992) 'Cognitive adaptations for social exchange', in J. H. Barkow, L. Cosmides and J. Tooby (eds), The Adapted Mind: Evolutionary Psychology and the Generation of Culture (New York: Oxford University Press).

Cox, G. W. (1997) Making Votes Count: Strategic Co-ordination in the World's Electoral Systems (Cambridge: Cambridge University Press).

Cox, G. W. and Munger, M. C. (1989) 'Closeness, expenditures, and turnout in the 1982 US House elections', American Political Science Review, 83:1, 217-231.

Crewe, I. (1981) 'Electoral participation', in D. Butler, H. R. Penniman and A. Ranney (eds), Democracy at the Polls: A Comparative Study of Competitive National Elections (Washington, DC: American Enterprise Institute).

Dennis, J. (1991) 'Theories of turnout: an empirical comparison of alienationist and rationalist perspectives', in W. Crotty (ed), Political Participation and American Democracy (New York: Greenwood Press).

Denver, D., Hands, G. and MacAllister, I. (2004) 'The electoral impact of constituency campaigning in Britain, 1992-2001', Political Studies, 52:2, 289-306.

Dowding, K. (2001) 'Rational choice and trust', Critical Review of International Social and Political Philosophy, 4:4, 207-220.

Downs, A. (1957) An Economic Theory of Democracy (New York: Harper and Row).

Dunleavy, P. (1997) 'A critique of pivotal choice theory', L'Annee Sociologique, 47:2, 55-83.

Dunleavy, P. and Margetts, H. (1995) 'The rational basis for belief in the democratic myth', in K. Dowding and D. King (eds), Preferences, Institutions and Rational Choice (Oxford: Clarendon Press).

Fedderson, T. J. and Pesendorfer, W. (1997) 'Voting behaviour and information aggregation in elections with private information', Econometrica, 65, 1029-1058.

Ferejohn, J. A. and Fiorina, M. P. (1974) 'The paradox of not voting: a decision theoretic analysis', American Political Science Review, 68, 525-536.

Ferejohn, J. A. and Fiorina, M. P. (1975) 'Closeness counts only in horseshoes and dancing', American Political Science Review, 69, 920-925.

Filer, J. E., Kenny, L. W. and Morton, R. B. (1993) 'Redistribution, income and voting', American Journal of Political Science, 37, 63-87.

Fischer, A. J. (1999) 'The probability of being decisive', Public Choice, 101, 267-283.

Franklin, M. N. (2004) Voter Turnout and the Dynamics of Electoral Competition in Established Democracies Since 1945 (Cambridge: Cambridge University Press).

Franklin, M. N., Niemi, R. G. and Whitten, G. (1994) 'Two faces of tactical voting, British Journal of Political Science, 24, 549-557.

Gellman, A., King, G. and Boscardin, W. J. (1998) 'Estimating the probability of events that have never occurred: when is your vote decisive?', Journal of the American Statistical Society, 93:441, 1-9.

Gimpel, J. G. and Schuknecht, J. E. (2003) 'Political participation and the accessibility of the ballot box', Political Geography, 22, 471-488.

Gintis, H. (2000) Game Theory Evolving (Princeton: Princeton University Press).

Goodin, R. E. and Roberts, K. W. S. (1975) 'The ethical voter', American Political Science Review, 69, 926-928.

Grafstein, R. (1991) 'An evidential decision theory of turnout', American Journal of Political Science, 35, 989-1010.

Grafstein, R. (1992) Institutional Realism (New Haven, NJ: Yale University Press).

Grafstein, R. (1999) Choice-Free Rationality: A Positive Theory of Political Behavior (Ann Arbor: Michigan University Press).

Green, D. P. and Shapiro, I. (1994) Pathologies of Rational Choice Theory (New Haven: Yale University Press).

Grofman, B. (1983) 'Models of voter turnout: a brief idiosyncratic view', Public Choice, 41, 55-61.

Grofman, B. (1993) 'Is turnout the paradox that ate rational choice theory?', in B. Grofman (ed), Information, Participation and Choice: An Economic Theory of Democracy in Perspective (Ann Arbor: University of Michigan Press). 
Grofman, B. (1996) 'Political economy: Downsian perspectives', in R. E. Goodin and H.-D. Klingemann (eds), A New Handbook of Political Science (Oxford: Oxford University Press).

Hinich, M. J. (1981) 'Voting as an act of contribution', Public Choice, 36, 135-140.

Hinich, M. J. and Munger, M. C. (1994) Ideology and the Theory of Political Choice (Ann Arbor: University of Michigan Press).

Imai, K. and King, G. (2004) 'Did illegal overseas absentee Ballots decide the 2000 US presidential election?', Perspectives on Politics, 2:3, 537-550.

Jackman, R. (1987) 'Political institutions and voter turnout in the industrial democracies', American Political Science Review, 81, 405-423.

Jackman, R. and Miller, R. A. (1995) 'Voter turnout in the industrial democracies during the 1980s', Comparative Political Studies, 27, 467-492.

Jeffrey, R. C. (1983) The Logic of Decision Theory (2nd edn) (Chicago: Chicago University Press).

Kahneman, D., Slovic, P. and Tversky, A. (1974) Judgement under Uncertainty: Heuristics and Biases (New York: Cambridge University Press).

Knack, S. (1992) 'Civic norms, social sanctions, and voter turnout', Rationality and Society, 4, 133-156.

Knack, S. (1993) 'The voter participation effects of selecting jurors from registration lists', Journal of Law and Economics, 36, 99-1 14.

Knack, S. (1994) 'Does rain help the Republicans? Theory and evidence on turnout and the vote', Public Choice, 79, 187-209.

Lapp, M. (1999) 'Incorporating groups into rational choice explanations of turnout: an empirical test', Public Choice, 98, 171-185.

Larcinese, V. (2000) 'Information acquisition, ideology and turnout: theory and evidence from Britain', unpublished.

Lassen, D. (2005) 'The effect of information on voter turnout: evidence from a natural experiment', American Journal of Political Science, 49:1, 103-118.

Ledyard, J. O. (1981) 'The paradox of voting and candidate competition: a general equilibrium analysis', in G. Horwich and J. Quirk (eds), Essays in Contemporary Fields of Economics (West Layfayette, IN: Purdue University Press).

Ledyard, J. O. (1984) 'The pure theory of large two-candidate elections', Public Choice, 44, 7-41.

Margolis, H. (1997) 'Probability of a tie vote', Public Choice, 31, 135-138.

Margolis, H. (1982) Selfishness, Altruism and Rationality: A Theory of Social Choice (Chicago: Chicago University Press).

Marwell, G. and Ames, R. E. (1981) 'Economists free-ride, does anyone else?', Journal of Public Economics, 15, 295-310.

Matsusaka, J. G. (1995) 'Explaining voter turnout patterns: an information theory', Public Choice, 84:1-2, 91-117.

Matsusaka, J. G. and Palda, F. (1993) 'The Downsian voter meets the ecological fallacy', Public Choice, 77, $855-878$.

Mattila, M. (2003) 'Why bother? Determinants of turnout in the European elections', Electoral Studies, $22,449-468$

Mayer, L. S. and Good, I. J. (1975) 'Is minimax regret applicable to voting decisions', American Political Science Review, 69, 916-917.

McLean, I. (1987) Public Choice: An Introduction (Oxford: Blackwell).

Mebane, W. R. Jr. (2004) 'The wrong man is president! Overvotes in the 2000 presidential election in Florida, Perspective on Politics, 2:3, 525-536.

Meehl, P. E. (1977) 'The selfish citizen paradox and the thrown-away vote argument', American Political Science Review, 71, 11-30.

Merrifield, J. (1993) 'The institutional and political factors that reduce turnout', Public Choice, 77:3, 657-669.

Milner, H. (2001) 'Social capital, civic literacy and political participation: explaining differences in voter turnout', in K. Dowding, J. Hughes and H. Margetts (eds), Challenges to Democracy: Ideas, Involvement and Institutions (Basingstoke: Routledge).

Morton, R. B. (1991) 'Groups in rational turnout models', American Journal of Political Science, 35:3, 758-776. 
Mueller, D. C. (1989) Public Choice II: A Revised Edition of Public Choice (New York: Cambridge University Press).

Mueller, D. C. (2003) Public Choice III (Cambridge: Cambridge University Press).

Mueller, D. C. and Stratmann, T. (2003) 'The economic effects of democratic participation', Journal of Public Economics, 87, 2129-2155.

Niemi, R. G. (1976) 'Costs of voting and nonvoting', Public Choice, 27, 115-119.

Niven, D. (2004) 'The mobilization solution? Face-to-face contact and voter turnout in municipal elections', Journal of Politics, 66:3, 868-884.

Olson, M. (1971) The Logic of Collective Action: Public Good and the Theory of Groups (2nd edn) (Cambridge, MA: Harvard University Press).

Owen, G. and Grofman, B. (1984) 'To vote or not to vote: the paradox of nonvoting', Public Choice, 42:3, 311-325.

Palfrey, T. R. and Rosenthal, H. (1983) 'A strategic calculus of voting', Public Choice, 41, 7-53.

Palfrey, T. R. and Rosenthal, H. (1985) 'Voter participation and strategic uncertainty', American Political Science Review, 79, 62-78.

Peters, E. (1998) 'The rational voter paradox revisited', Public Choice 97, 179-195.

Plutzer, E. (2002) 'Becoming a habitual voter: inertia resources, and growth in young adulthood', American Political Science Review, 96, 41-56.

Powell, G. B. (1980) 'Voting turnout in thirty democracies', in R. Rose (ed), Electoral Participation (Beverly Hills, CA: Sage).

Powell, G. B. (1982) Contemporary Democracies: Participation, Stability and Violence (Cambridge, MA: Harvard University Press).

Powell, G. B. (1986) 'American voter turnout in comparative perspective', American Political Science Review, $80,17-45$.

Putnam, R. D. (2000) Bowling Alone: The Collapse and Revival of American Community (New York: Simon and Schuster).

Riker, W. H. and Ordeshook, P. C. (1968) 'A theory of the calculus of voting', American Political Science Review, 62, 25-43.

Shachar, R. and Nalebuff, B. (1999) 'Follow the leader: theory and evidence on political participation', American Economic Review, 89, 525-547.

Schuessler, A. A. (2000) 'Expressive Voting', Rationality and Society, 87-119.

Schuessler, A. A. (2001) A Logic of Expressive Choice (Princeton: Princeton University Press).

Schur, L. A. (2000) 'What determines voter turnout: lessons from citizens with disabilities', Social Science Quarterly, 81:2, 571-587.

Schwartz, T. (1987) 'Your vote counts on account of the way it is counted', Public Choice, 54, 101-121.

Smith, J. W. (1975) 'A clear test of rational voting', Public Choice, 23, 55-67.

Stigler, G. (1972) 'Economic competition and political competition', Public Choice, 13, 91-106.

Tullock, G. (1967) Toward a Mathematics of Politics (Ann Arbor: University of Michigan Press).

Udehn, L. (1996) The Limits of Public Choice: A Sociological Critique of the Economic Theory of Politics (London: Routledge).

Uhlaner, C. J. (1989a) 'Rational turnout: the neglected role of groups', American Journal of Political Science, $33,390-422$.

Uhlaner, C. J. (1989b) "Relational goods" and participation: incorporating sociobility into a theory of rational action', Public Choice, 62, 253-285.

Uhlaner, C. J. (1993) 'What the Downsian voter weighs: a reassessment of the costs and benefits of action', in B. Grofman (ed), Information, Participation and Choice: An Economic Theory of Democracy in Perspective (AnnArbor: University of Michigan Press).

Wuffle, A. (1999) 'Credo of a "reasonable choice" modeller', Journal of Theoretical Politics, 11:2, 203-206. 